\title{
Review \\ Function of Connexin-43 in Macrophages
}

\author{
Daniel Rodjakovic ${ }^{1,2}$, Lilian Salm ${ }^{1,2} \mathbb{D}$ and Guido Beldi $1,2, *$ (D) \\ 1 Department for Visceral Surgery and Medicine, Bern University Hospital, University of Bern, CH-3010 Bern, \\ Switzerland; daniel.rodjakovic@dbmr.unibe.ch (D.R.); lilian.salm@dbmr.unibe.ch (L.S.) \\ 2 Department for BioMedical Research (DBMR), Bern University Hospital, University of Bern, \\ CH-3008 Bern, Switzerland \\ * Correspondence: guido.beldi@insel.ch; Tel.: +41-(0)-31-632-59-00
}

\section{check for} updates

Citation: Rodjakovic, D.; Salm, L.; Beldi, G. Function of Connexin-43 in Macrophages. Int. J. Mol. Sci. 2021, 22, 1412. https://doi.org/10.3390/ ijms22031412

Academic Editor: Mathieu Vinken Received: 10 December 2020

Accepted: 26 January 2021

Published: 30 January 2021

Publisher's Note: MDPI stays neutral with regard to jurisdictional claims in published maps and institutional affiliations.

Copyright: (c) 2021 by the authors. Licensee MDPI, Basel, Switzerland. This article is an open access article distributed under the terms and conditions of the Creative Commons Attribution (CC BY) license (https:/ / creativecommons.org/licenses/by/ $4.0 /)$.

\begin{abstract}
Recent studies have helped to increase the understanding of the function of Connexin-43 (Cx43) in macrophages $(\mathrm{M} \varphi)$. The various roles of $\mathrm{Cx} 43$ in $\mathrm{M} \varphi$ s range from migration, antigenpresentation and some forms of intercellular communication to more delicate processes, such as electrochemical support in the propagation of the heartbeat, immunomodulatory regulation in the lungs and in macrophage-differentiation. Its relevance in pathophysiology becomes evident in inflammatory bowel disease (IBD), tumours and HIV, in which aberrant functioning of Cx43 has been described. However, the involvement of $\mathrm{Cx} 43$ in other $\mathrm{M} \varphi$ functions, such as phagocytosis and polarisation, and its involvement in other types of local and systemic inflammation, are still unclear and need further research.
\end{abstract}

Keywords: connexin; hemichannel; gap junction; physiology; pathophysiology; mechanisms; connexin-43; Cx43; gja1; macrophage

\section{Introduction}

Macrophages $(\mathrm{M} \varphi)$ have been studied for well over a hundred years [1]. Their function as phagocytic cells and as a first line of defense against pathogens was initially documented in historic work in bacteria [2,3]. Over the years, $\mathrm{M} \varphi$ s were found to be involved in processes such as regenerative responses [4], inflammation of systemic organs [5,6], tumour-killing [7], hypercholesterolemia [8], sepsis [9] as well as many others. These findings increasingly established $\mathrm{M} \varphi \mathrm{s}$ as a diverse and heterogenic cell type of the immune system [10]. Subsequently, some of these newly found functions were discovered to be intertwined with the multifaceted protein connexin-43 (Cx43).

Connexins, in general, are essential gap-junction proteins, which enable intercellular communication via the transfer of ions and signaling molecules between cells, by forming hemichannels [11,12]. Six connexin proteins form these hexameric structures. Hemichannels are transported to the plasma membrane, where they can dock with other channels in closely adjacent cells, forming gap junction channels. These gap junction channels can accumulate in the thousands in the form of gap junction plaques, to exchange information between cells, until they are internalized as vesicles, which contain the junctional membrane of both adjacent cells. Hemichannels are also involved in long-range direct cell-to-cell communication via nano-tubes, paracrine communication in the form of undocked hemichannels/pores [13] and various other processes [14]. Mutations in connexins cause disorders ranging from changes in the skin, cataracts, and hearing loss to complex syndromes [15] and embryo lethal mutations [16].

Cx43, also known as GJA1, is one of these connexins. It is prominently featured in the immunological synapse [17], thus making it the prime target for investigations in immune cells, such as M $\varphi s$. In M $\varphi s, C x 43$-dependant intercellular signal transfer is involved in a plethora of physiological and pathophysiological processes, such as immunomodulation [18,19], regulation of the heartbeat [20] and purinergic signaling [9]. Therefore, Cx43 
acts as a gateway to the $\mathrm{M} \varphi$ s outer-world, as much as it allows the environment to influence $\mathrm{M} \varphi s$ and the expression of $\mathrm{Cx} 43$ itself $[9,21,22]$.

This review summarizes the current literature regarding the role of $\mathrm{C} x 43$ in $\mathrm{M} \varphi \mathrm{s}$ during physiological as well as pathophysiological processes. Deviations into other cell types, such as monocytes, are kept short and serve the purpose of clarification of Cx43function in $\mathrm{M} \varphi \mathrm{s}$.

Lastly, it is important to note, that the investigations into $C x 43$ in relation to $M \varphi s$ are limited, since the homozygous $\mathrm{C} \times 43$ knockout is lethal in mice due to heart failure $[16,23]$. These circumstances have led to studies making use of different circumventions, such as heterozygous mice $[24,25], \mathrm{M} \varphi-\mathrm{C} \times 43$ specific knockout mice $[9,18]$ and fetal liver cell transplantation from homozygous Cx43 knockout mice into irradiated recipient-mice [26], as discussed below.

\section{Dawdling and Devouring: Rolling around for Initiative}

$\mathrm{M} \varphi s$ are essentially phagocytic cells. They migrate, phagocytose and present antigens to other cells of the immune system.

\subsection{Migration}

The expression of Cx43 in lymphocytes was proposed as early as 1997, as the potential interaction between $\mathrm{M} \varphi \mathrm{s}$ and the vessel wall endothelium during infiltration was considered [8]. However, blocking connexins with connexin mimetic peptides had little influence on $\mathrm{M} \varphi$ transendothelial migration [27]. The influence of $\mathrm{Cx} 43$ in $\mathrm{M} \varphi$-migration was further investigated in studies using cells from heterozygous Cx43 knockout mice [24,25]. Interestingly, newer studies present $\mathrm{M} \varphi-\mathrm{Cx} 43$ as not only being capable of regulating the migratory ability of $\mathrm{M} \varphi \mathrm{s}$, but also as influencing the migration of other cells [24,28].

Increases in Cx43 expression consequently enhances the migratory ability of $M \varphi s$ [25]. Intriguingly, the expression of $\mathrm{Cx} 43$ in $\mathrm{M} \varphi \mathrm{s}$ is increased in lipopolysaccharide (LPS) conditioned medium $[9,22,29]$. This was identified during a transwell-assay with LPSconditioned medium, in which Cx43 expression was found to be increased. However, migration can be inhibited by immunosuppressive drugs, such as mTOR inhibitors and steroids, as well as by downregulation of Cx43 expression [25].

Moreover, the transmigratory behavior of freshly isolated human $\mathrm{M} \varphi \mathrm{s}$, was analyzed in a blood-brain barrier model [21]. They were pretreated with TNF- $\alpha$ plus IFN- $\gamma$ to induce $\mathrm{C} \times 43$ expression. It was found that transmigration was associated with the formation of heterocellular gap junctions in-between monocytes/M $\varphi s$ and endothelial cells. Blocking the gap junctions reduced the number of $\mathrm{M} \varphi \mathrm{s}$, which were found to have transmigrated across the model. After transmigration, $\mathrm{Cx} 43$ was prominently found by staining in monocytes $/ \mathrm{M} \varphi \mathrm{s}$, endothelial cells, and astrocytes, while being more intense at heterocellular contacts [21].

Furthermore, altered secretion of signaling molecules by heterozygous Cx43 M $\varphi$ s, decreased migration of other cells, such as smooth muscle cells [24]. The same was found for neutrophils, although this was not the case for $\mathrm{M} \varphi$ s from homozygous fetal livers [28]. Moreover, heterozygous $\mathrm{C} \times 43 \mathrm{M} \varphi$ s have also been identified as altering the progression of diseases, such as atherosclerosis, by influencing cell migration. Atherosclerosis progression was found to be less prominent in $\mathrm{C} \times 43$ heterozygous mice, as their plaques contain significantly fewer neutrophils, due to reduced $\mathrm{M} \varphi$-induced chemotaxis and subsequent accumulation [28]. Overall, influence over the $\mathrm{M} \varphi$ s-microenvironment is closely tied to $\mathrm{Cx} 43$ and will be discussed more thoroughly in chapter three through to chapter five.

\subsection{Phagocytosis}

After arriving at the inflammation site by migration or transmigration, $\mathrm{M} \varphi$ s start to phagocytose, engulfing and digesting pathogens, thus acting as first line responders of the innate immune system. 
Cx43 was initially proposed to be involved in phagocytosis, as various functions, some of which are essential in phagocytosis, were found to rely upon connexins. However, this was later found to not be the case, as described in the conflicting results below.

Anand R.J. et al. found significant, although partial inhibition of phagocytosis in heterozygous Cx43 knockout mice and oleamide-inhibited murine $\mathrm{M} \varphi \mathrm{s}$ [30]. They obtained heterozygote $\mathrm{C} \times 43$ knockout $\mathrm{M} \varphi$ s via peritoneal lavage from heterozygote mice and homozygous Cx43 knockout $\mathrm{M} \varphi$ s from the embryonic livers of homozygous knockout mice. The cells were identified as $\mathrm{M} \varphi$ s based upon their surface expression of CD45 [30] using coverslips [31]. The $\mathrm{M} \varphi$ s were given sheep erythrocytes, latex beads, and Escherichia coli to phagocytose and were then evaluated by light and confocal microscopy [30].

Glass A.M. et al. on the other hand found no difference in the phagocytic capabilities between wild type and $\mathrm{C} x 43$ knockout $\mathrm{M} \varphi \mathrm{s}$ [26]. They obtained $\mathrm{M} \varphi$ s through peritoneal lavage and bone marrow harvesting from previously irradiated chimeric mice, which were reconstituted with homozygous $\mathrm{C} \times 43$ knockout fetal liver cells. The cells were then identified by flow cytometry as CD11b and F4/80 double positive. $\mathrm{M} \varphi$ s were given sheep erythrocytes, zymosan particles and Listeria monocytogenes while their phagocytic ability was measured by fluorescent microscopy and flow cytometry. Glass A.M. et al. criticized the methodology used by Anand R.J. et al., as CD45 is widely accepted as being present in multiple cell types derived from hematopoietic cells and not just on $M \varphi s$ [26], unlike $\mathrm{F} 4 / 80$, which is specific to murine $\mathrm{M} \varphi \mathrm{s}$ [32].

Another recent study by Dosch M. et al. found phagocytosis to be independent of $\mathrm{C} \times 43$ [9]. The $\mathrm{M} \varphi$ s were obtained from conditional $\mathrm{M} \varphi$ Cx43 knockout mice via peritoneal lavage. The cells were incubated with latex beads and evaluated with a phagocytosis assay kit. Neither pharmacological blocking with Gap27 nor Cx43 deletion altered phagocytosis [9].

It is unclear, if the different methodologies, i.e., derivation of $\mathrm{M} \varphi s$ and material used to phagocytose, may have impacted the $\mathrm{M} \varphi \mathrm{s}$ ability to properly perform phagocytosis. More studies covering different methodologies are needed to further investigate targetdependent phagocytosis.

\subsection{Antigen-Presentation}

$\mathrm{M} \varphi \mathrm{s}$ and dendritic cells (DCs) were found to cooperate in the uptake, transfer, and presentation of antigens [33]. Different possibilities for Cx43-dependent antigen transfer were discussed, until the transfer of loaded major histocompatibility complex (MHC) class II molecules was proposed to be Cx43-dependant trogocytosis, as molecules from donor cells were detected on the surface of acceptor cells [33]. Trogocytosis is a process whereby lymphocytes extract surface molecules of antigen presenting cells and express them on their own membrane [34-36]. MHC class I presentation on the other hand, was found to be identical between wild type and homozygous $\mathrm{C} \times 43$ knockout $\mathrm{M} \varphi \mathrm{s}$, in the case of Listeria monocytogenes infection [26]. Of note, $\mathrm{M} \varphi \mathrm{s}$ with deletion of $\mathrm{C} \times 43$ are more proficient in $\mathrm{T}$ cell priming. The mechanism behind this, is postulated to be an increased accumulation of antigens, since these $\mathrm{M} \varphi$ s are unable to transfer them to neighboring DCs, which leads to efficient presentation [33].

However, antigen presentation is not the only Cx43-dependant intercellular communication in $\mathrm{M} \varphi \mathrm{s}$, as described in the following chapter.

\section{Intercellular Communication Is a Two-Way Street}

Intercellular communication is essential for the function of the immune system, and the established connections between $\mathrm{M} \varphi$ s and parenchymal cells exhibit Cx43 dependent functions. Cx43-dependent communication by $\mathrm{M} \varphi$ s has also been proven to be essential in non-immune functions, such as the regulation of the heartbeat [20] and diseases, such as HIV [37]. 


\subsection{Physiological Communication in Heart, Lung and Intestine}

3.1.1. Electrochemical Communication of the Heart

$\mathrm{M} \varphi s$ are well known to influence cardiac disease and repair [38]. However, they have only recently been implicated in a nonimmune context [39]. $\mathrm{M} \varphi \mathrm{s}$ in the $\mathrm{AV}$ node, as well as the left and right ventricular walls, all express Cx43. FACS-sorted cells were used to identify expression, to eliminate potential cross contamination with Cx43 high-expressing cardiomyocytes. Cx43 was then analysed in $\mathrm{M} \varphi$ s by whole-mount immunofluorescence. It was found to be marked on punctate contacts between $\mathrm{M} \varphi s$ and cardiomyocytes. Electron microscopy then confirmed direct cellular contact. This led to the conclusion, that $\mathrm{M} \varphi \mathrm{s}$ couple to cardiomyocytes using Cx43 containing gap junctions. The $M \varphi s$ do so primarily in the distal part of the AV node. Interestingly, these $\mathrm{M} \varphi$ s regulate the heartbeat by reducing the action potential and aiding in repolarisation, thus allowing higher conduction rates. This was confirmed by $\mathrm{M} \varphi$ ablation using diphtheria toxin, which led to an AV block.

Furthermore, $\mathrm{M} \varphi \mathrm{C} \times 43$ is also speculated to be involved in additional abnormalities of the atria and ventricles, such as atrial fibrillation and ischemia-induced ventricular arrhythmias [20].

\subsubsection{Immunomodulatory Communication in the Lungs}

The involvement of $\mathrm{C} x 43$ in alveolar $\mathrm{M} \varphi$ s has also only recently been described $[18,19]$. By using real-time in situ imaging, alveolar $\mathrm{M} \varphi$-epithelium gap junction channels containing Cx43 were identified by Westphalen K. et al. After inducing inflammation with LPS, alveolar CD11 $c^{\text {cre/cre }} \mathrm{Cx} 43^{\text {floxed/floxed }} \mathrm{M} \varphi$ s remained sessile and attached themselves to the alveoli. To investigate, if $\mathrm{C} x 43$ may be responsible for the $\mathrm{M} \varphi$-immobility, bacteria and PBS were microinjected and the cells observed. $M \varphi s$ were found to rapidly ingest the bacteria, yet they remained sessile. The study also found neutrophils freely entering and migrating ruling out non-specific physical factors. Hence, it was concluded, that Cx43 was not responsible for $\mathrm{M} \varphi$-immobility. Cx43 was found to play another role in these sessile M $\varphi$ s. They were found to utilize the epithelium as a conducting pathway, communicating by synchronized $\mathrm{Ca}^{2+}$ waves. This intercellular communication was found to be immunosuppressive: activating Akt $\mathrm{Ca}^{+}$-dependently [18], a serine/threonine kinase which influences cell survival, growth, proliferation, angiogenesis, metabolism, and migration [40]. Cx43 knockout alveolar $\mathrm{M} \varphi \mathrm{s}$ were also identified increasing secretion of proinflammatory cytokines themselves (MIP- $1 \alpha$ ) and in the epithelium (CXCL1,5), indicating mutual cytokine suppression. Additionally, Cx43 knockout $\mathrm{M} \varphi$ s enhanced the alveolar recruitment of neutrophils [18].

Similar findings were also seen in human cells. Beckmann A. et al. investigated the communication between a bilayer of human $\mathrm{M} \varphi$ s and human alveolar epithelial cells. The goal was to identify if $\mathrm{M} \varphi$-epithelial gap junctions exist in humans. Interestingly, co-cultures were found to express $C x 43$, whereas isolated $M \varphi s$ did not [19]. These results lay a cornerstone for future research, concerning $C x-43$ dependent $M \varphi$ immunomodulation in the lungs, as well as presenting potential targets for medical treatment.

\subsubsection{Intercellular Communication in the Intestine}

Aside from cardiomyocytes [20] and alveolar epithelium [18,19], M $\varphi$ s were also found to communicate with the epithelium of the intestine. $\mathrm{M} \varphi \mathrm{s}$ use $\mathrm{C} \times 43$ to form functional gap junctions with the epithelial cells and use paracrine and heterocellular signaling to communicate. This communication is directly involved in inflammatory bowel disease (IBD) (see below) [41].

\subsection{Pathological Communication in IBD, Tumors and HIV}

The use of $\mathrm{C} \times 43$ in intercellular communication is not exclusive to physiological processes: IBD, tumors and HIV are some of the diseases involving aberrant use of $\mathrm{M} \varphi \mathrm{Cx} 43$. 


\subsubsection{IBD}

$\mathrm{M} \varphi$ s establish communication with epithelial cells using Cx43, this communication then contributes to the dysregulation of the intestinal epithelial barrier in IBD [41]. Interestingly, connexin expression in IBD tissues is relocated more basolaterally in epithelial cells, compared to normal tissue. This phenomenon may facilitate the interaction of intestinal epithelial cells with infiltrating $\mathrm{M} \varphi \mathrm{s}$, allowing for disease progression. Intestinal epithelial cells were therefore seeded in six-well plates on top of activated $\mathrm{M} \varphi$ s to mimic the observed architecture in the intestinal tissue. Under optimal conditions, calcein dye transfer could be seen by a shift in fluorescence, demonstrating its transfer from epithelial cells to $\mathrm{M} \varphi \mathrm{s}$ [41].

Nevertheless, such remodulation of cellular structures, as seen in IBD, is just a mild example of cellular reorganization, a more extreme example can be found in tumors.

\subsubsection{Filopodia in Tumor Networks and HIV}

By immunostaining for $\mathrm{M} \varphi$ markers, tumor-associated $\mathrm{M} \varphi \mathrm{s}$ (TAM) were found in anaplastic thyroid tumors [42]. These TAMs establish a variety of intercellular contacts inbetween themselves, as well as with other cancer cells. Contacts are established using long, irregular, thin, moniliform cytoplasmic processes, which express Cx43 at their tip. These cytoplasmic processes are described as nanotube-like, yet it is unclear if they are indeed nanotubes. The direct contact with other $\mathrm{M} \varphi \mathrm{s}$, cancer cells and blood vessels may allow communication and molecular transfer. TAMs are both evenly intermingled with cancer cells, as well as located in long chains, which derive from perivascular clusters across the tumor. These networks are robust and resilient structures, which allow for an advantage on the neighboring non-tumor tissues. By allowing intercellular passage of numerous molecules and ions, $\mathrm{Cx} 43$ has been shown to act as the main culprit in the coordination in intercellular signaling and efficient metabolic support in cancer cell networks. This is shown by the fact that many tumor cells were found to be more than 150 microns away from blood vessels, without any signs of necrosis or apoptosis, even though this distance is thought to represent the maximum distance of oxygen diffusion from blood vessels into the tissue [42].

Unlike the presumed nanotubes in TAMs, HIV does in fact exploit Cx43-containing tunnelling-nanotubes (TNT). In HIV-infected $\mathrm{M} \varphi \mathrm{s}$, Cx43 expression is induced three days post infection and remains high. The gap-junctions formed between infected and uninfected $\mathrm{M} \varphi$ s were proven to be functional by identifying Lucifer Yellow diffusion in-between these cells. No dye uptake was observed when extracellular dye was presented to infected and uninfected $\mathrm{M} \varphi \mathrm{s}$, suggesting that Cx43 hemichannels are only present at the tip of the TNT. The study concludes that TNTs are required for efficient intercellular communication and viral spread, hence selective $\mathrm{C} \times 43$ blocking may present itself as future therapeutic target against HIV [37].

\section{A Microenvironment with Macro-Consequences}

The $\mathrm{M} \varphi$ 's interaction with the microenvironment itself provides an alternative to direct cell-to-cell contacts and serves as a much broader form of communication. Physiological and pathophysiological processes alter the $\mathrm{M} \varphi$ s environment, thus changing its expression of $\mathrm{Cx} 43[22,25,29]$. The change in $\mathrm{Cx} 43$ expression furthermore influences the $\mathrm{M} \varphi \mathrm{s}$ gene expression for chemokine secretion or activation of the complement pathway [28]. Moreover, $\mathrm{Cx} 43$ deletion also alters the release of molecules, such as adenosine triphosphate (ATP) [9].

\subsection{The Environment Changes the M $\varphi$ : LPS, Acute Peritonitis and Sepsis}

Inflammatory sites, in which $\mathrm{M} \varphi$ s aggregate, are proposed to influence connexin channels [21]. Although, LPS was once found to inhibit lymphocyte-M $\varphi$ communication via an unclear mechanism [43], some recent studies found LPS-induced Cx43 expression [22] and increase in intercellular communication, measured by dye transfer [44]. Cx43 expression in bone marrow-derived $\mathrm{M} \varphi$ s increased in a dose- and time-dependent manner during 
contact with LPS [22]. The same reaction was found for rat liver Kupffer cells. Cx43 was found to be predominantly localized at the cell to cell interfaces, thus indicating gap junction formation and probable intercellular communication between Kupffer cells in vivo. In vitro, Kupffer cells were in fact found to increase dye transfer after the administration of LPS and IFN-gamma, which correlates with increased Cx43 expression [44]. This may be interpreted as a higher communication rate $[37,41,44]$. It was also found that the LPSdependant induction of $\mathrm{C} x 43$ in $\mathrm{M} \varphi$ s via the iNOS pathway, can be significantly decreased by tacrolimus and methylprednisolone, two commonly administered immunosuppressive drugs used after solid organ transplantation [25].

Specific infectious diseases, such as the infection with Mycobacterium tuberculosis, can also increase expression of $\mathrm{Cx} 43$, thus enhancing intercellular communication, which leads to an increase in the apoptosis rate and expression of inflammatory factors [45]. It is also important to note, that murine peritoneal $\mathrm{M} \varphi s$ - which are in contact with LPS and ATP-induce other inflammatory processes, such as the activation of the NLRP3 inflammasome. Moreover, NLRP3 inflammasome activation was found to be intertwined with Cx43 expression, as heterozygous $\mathrm{Cx} 43 \mathrm{M} \varphi$ s have been shown to decrease inflammasome activation. In addition, they changed intracellular redox modulation, progressing renal inflammatory cell injury [29].

But what happens when the pathological burden of an infection overthrows the immune system? Murine models were used to assess the relation of Cx43-functionaility and mortality in sepsis and acute peritonitis. $\mathrm{M} \varphi \mathrm{C} \times 43$ function was found to be inversely correlated with mortality, as heterozygous Cx43 mice and pharmacologically Cx43-blocked mice show increased mortality in sepsis [30] and acute peritonitis [22]. Intriguingly, the opposite was reported in a murine sepsis model with $\mathrm{M} \varphi$-specific depletion of Cx43 [9]. Furthermore, $\mathrm{C} \times 43$ positive $\mathrm{M} \varphi \mathrm{s}$ were found in the human peritoneal cavity of patients with peritonitis, but not in control patients, suggesting the involvement of $\mathrm{M} \varphi \mathrm{C} \times 43$ in septic processes in humans [9].

\subsection{The M $\varphi$ Changes the Environment: ATP Release}

Peritonitis was found to increase extracellular ATP levels, suggesting the involvement of $\mathrm{M} \varphi \mathrm{s}$ in systematic ATP release during sepsis [9]. Extracellular ATP is utilized as autocrine regulation and paracrine communication by immune cells [46]. Active ATP-release from inflammatory cells can occur both via vesicular exocytosis and via hemichannels, including Cx43 [47,48]. The ATP-release allows for multifunctional modulation of the cell, tissue, and organism [49].

Cx43 and P2X7 purinergic receptors have been found to be co-localized on peritoneal $\mathrm{M} \varphi \mathrm{s}$ [50]. ATP-release from $\mathrm{M} \varphi \mathrm{s}$ occurs in response to TLR-2 and TLR-4 activation in a Cx43-dependant manner [9]. After the release, ATP typically activates P2 receptors [51-54]. These results therefore support the findings already made for the P2Y1 receptor $[55,56]$, and other immune cells $[51,57]$. The findings indicate the possible involvement of Cx43dependant ATP-release in a variety of situations, including certain inflammatory diseases [58], as well as physiological situations, i.e., intercellular immunomodulation in the lungs, as established by Westphalen K. et al. [18] (see Section 3.1.2).

\section{M $\varphi$ s Dress for the Job They Want}

\subsection{Adapting to Their Environment: Polarisation}

$\mathrm{M} \varphi s$ can adapt according to changes in their microenvironment by polarization [59]. The subtypes are commonly summarized and simplified in M1 and M2 M $\varphi$ s, even though polarisation is rather a spectrum than a switch [59-61]. The types differ in their functions:

- $\quad \mathrm{M} 1 \mathrm{M} \varphi$ s accumulate at the inflammation site by strong adhesion, which promotes cell retention and the progression of inflammation [62];

- $\quad \mathrm{M} 2 \mathrm{M} \varphi s$ possess stronger migratory ability compared to M1 M $\varphi s$, have increased phagocytic properties, and are in general anti-inflammatory and considered to help with tissue repair $[62,63]$. 
Morel S. et al. found that mice with Cx43-heterozygous M $\varphi$ s do not differ from homozygous knockout mice or wild type $\mathrm{M} \varphi \mathrm{s}$ in terms of M1 and M2 polarization [28]. These $M \varphi s$ were derived from haematopoietic fetal liver cells, which were transferred to lethally irradiated mice [28]. The absence in change of polarization was recently confirmed for peritoneal M2 M $\varphi$ s under Cx43 blocking or deletion.

However, markers for M1 differentiation, such as iNOS and Il12RB, were found to be decreased under $\mathrm{C} \times 43$ blocking or deletion [9]. The diminished $\mathrm{M} 1 \mathrm{M} \varphi$ polarization may be due to the Cx43-dependant polarisation via Angiotensin-2 (Ang-2) [64], as Ang-2 was identified as having decisive roles in inflammation: increasing adhesion molecules, cytokines, chemokines and more [65]. This may therefore influence $\mathrm{M} \varphi$ polarisation in experiments, in which mice undergo inflammation, as is the case in the latter mentioned study [9].

The discrepancy in regard to the influence of $\mathrm{Cx} 43$ in $\mathrm{M} \varphi$ polarization to the M1 type, may alternatively be due to the inherent difficulties in identifying the $M \varphi$ polarization, as markers used for identification of polarization in vitro were found to not always work in vivo. For instance, genes modulated inside the iNOS signaling pathway were found to differ slightly compared to in vitro $\mathrm{M} \varphi s$ [66].

\subsection{Adapting to Their Environment: Differentiation}

$\mathrm{M} \varphi \mathrm{s}$ also adapt to their environment by differentiation. In two settings, differentiation was found to involve the use $\mathrm{C} \times 43$ in either formation or function.

\subsubsection{Foam Cells}

Lipid-laden foam cells form when $\mathrm{M} \varphi$ s retain too much cholesterol, thus becoming the prototypical cells associated with atherosclerotic plaque [67]. Foam cells in rabbits, which had hypercholesterolemia-induced atherosclerosis, were found to express Cx43, however precursor monocytes in normocholesterolemic rabbits were not. Cx43 expression in $\mathrm{M} \varphi \mathrm{s}$ was observed to be similar in animals which were mechanically injured by balloon injury and had hypercholesterolemia, as well as those which only had hypercholesterolemia. Moreover, neither alveolar $\mathrm{M} \varphi \mathrm{s}$, Kupffer cells nor $\mathrm{M} \varphi \mathrm{s}$ from peritoneal or bronchial lavage from normo- and hypercholesterolemic rabbits were identified as inducing $\mathrm{Cx} 43$ expression. This contradiction of previous papers may be due to the choice of laboratory animals or methodology [8].

\subsubsection{Foreign Body Giant Cells}

In response to biomaterials in bones, foreign body giant cells (FBGC) may form, which are derived from precursors of the monocyte $/ \mathrm{M} \varphi$ lineage $[68,69]$. Implanted biomaterial in minipig femura yields $\mathrm{C} x 43$ positive $\mathrm{M} \varphi \mathrm{s}$ and FBGCs. The expression was identified by immunohistochemistry, Western Blot and in situ hybridization, additionally, ultrastructural analysis of gap junctions was performed. Thus, expression of Cx43 in FGBCs and M $\varphi$ s was found in the granulation tissue and on the surface of the implanted biomaterial [68]. Cx43 labelling on the protein and mRNA level was attributed to ultrastructurally identified gap junctions between $\mathrm{M} \varphi s$, between FBGCs and between FBGCs and $\mathrm{M} \varphi \mathrm{s}$ [68]. Furthermore, the formation of FBCG could also be shown ultrastructurally. Hence, the conclusion can be reached, that $\mathrm{C} \times 43$ seems to play a role in the formation of osteoclast-like FBGCs [68]. Moreover, a subsequently performed experiment, using Cx43 and microfilament labelling suggests the possible role of podosome and hemichannels in biomaterial degradation, utilizing Cx43 [69].

\section{Conclusions}

The function of $\mathrm{Cx} 43$ on immune cells, such as $\mathrm{M} \varphi \mathrm{s}$, is difficult to study, yet seems to provide useful insights to its critical importance. Only a few papers have been published, which selectively investigated floxed $\mathrm{C} \times 43 \mathrm{M} \varphi \mathrm{s}$. Thus, a substantial amount of the currently available research is gathered from either homozygous $\mathrm{M} \varphi \mathrm{s}$, which were collected from 
fetal organs and transplanted into a host or from heterozygous M $\varphi$ s. It is unclear if the lack of Cx43 may have initiated the expression of other connexins as a compensatory mechanism, or if alternative factors influenced the sometimes-contradictory results obtained from the experiments.

Nevertheless, Cx43 and $\mathrm{M} \varphi$ functions remain closely intertwined, as Cx43 is critical in various physiological and pathophysiological processes. This includes interactions with neighboring cells, the microenvironment, migration to inflammation sites, antigenpresentation, immunomodulation, as well as supporting macro physiological functions such as heartbeat-regulation. Diseases like IBD, HIV, sepsis and other infections all depend on-and are modulated by-Cx43. Therefore, it is likely that Cx43 is also of importance in $M \varphi$ function in other types of diseases, that remain to be explored in future studies. The research on the intricate and versatile functions of Cx43 in M $\varphi$ s would allow for the establishment of specific drug targeting and modulation of the innate and adaptive immune system, thus contributing to current fields of interest for $\mathrm{M} \varphi$ research, such as polarization, intercellular communication, inflammation, wound healing and more.

A summary of some select $\mathrm{C} \times 43$ functions in $\mathrm{M} \varphi \mathrm{s}$ can be found in Figure 1 . The figure depicts mechanisms, which show its diverse roles as a pore in the micro-environment, as well as in direct cell-to-cell contacts, in lung, heart and disease.

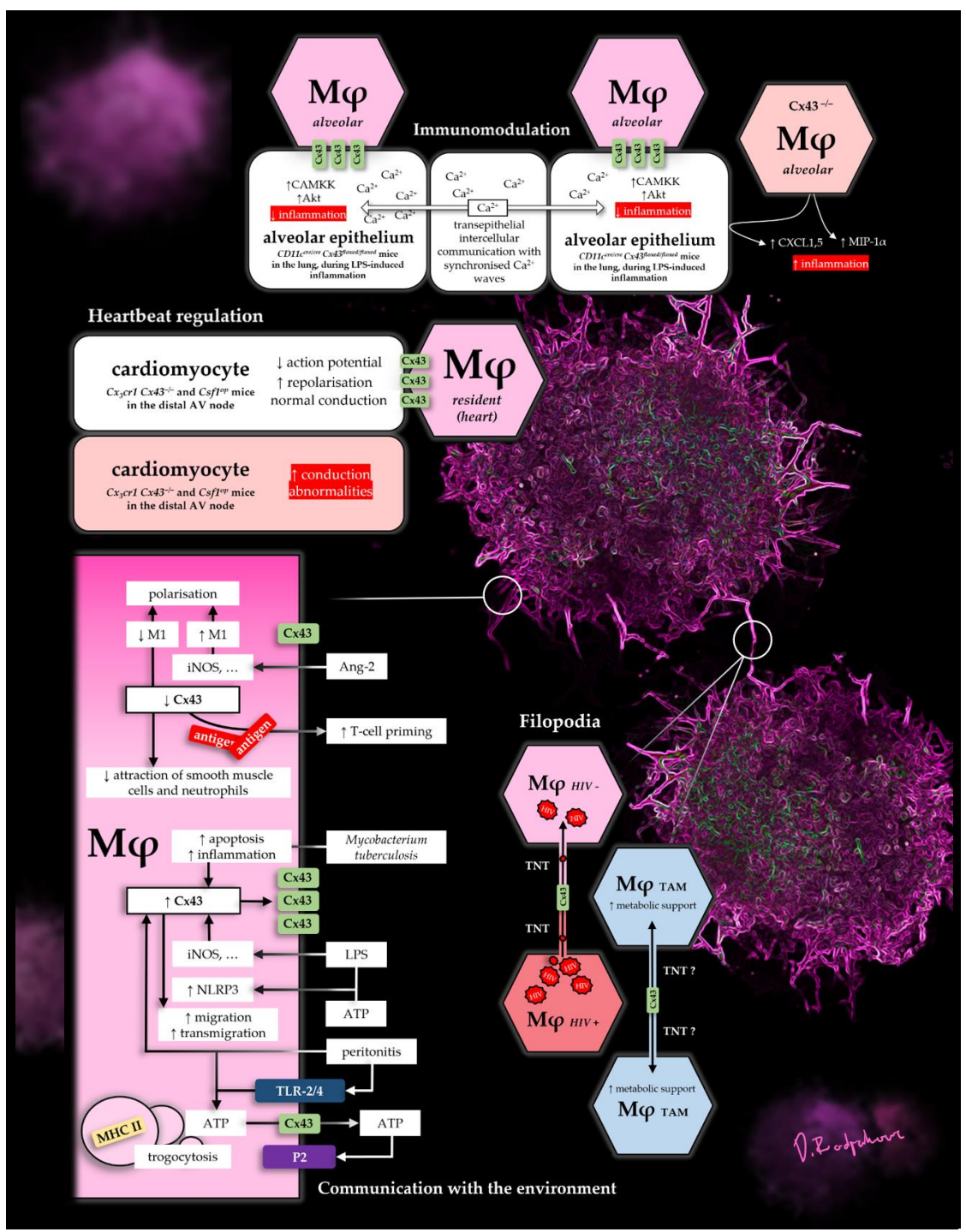

Figure 1. Selection of $\mathrm{C} x 43$-dependant $\mathrm{M} \varphi$ functions. 
Funding: G. Beldi receives funding from the Swiss National Science Foundation (166594).

Conflicts of Interest: The authors declare no conflict of interest.

$\begin{array}{ll}\text { Abbreviations } \\ \text { Ang-2 } & \text { Angiotensin-2 } \\ \text { ATP } & \text { Adenosine triphosphate } \\ \text { Cx43 } & \text { Connexin-43 } \\ \text { DC } & \text { Dendritic cell } \\ \text { FBGC } & \text { Foreign body giant cell } \\ \text { IBD } & \text { Inflammatory bowel disease } \\ \text { M } \varphi & \text { Macrophage } \\ \text { TAM } & \text { Tumor-associated-macrophage } \\ \text { TNT } & \text { Tunneling-nanotube }\end{array}$

\section{References}

1. Mečnikov, É. Leçons sur la Pathologie Comparée de L'inflammation; Bibliothèque des Annales de L'Institut Pasteur: Paris, France, 1892.

2. Evans, H.M.; Bowman, F.B.; Winternitz, M.C. An experimental study of the histogenesis of the miliary tubercle in vitally stained rabbits. J. Exp. Med. 1914, 19, 283-302. [CrossRef] [PubMed]

3. Cecil, R.L. A study of experimental non-hemolytic streptococcus lesions in vitally stained rabbits. J. Exp. Med. 1916, 24, 739-758. [CrossRef] [PubMed]

4. Wynn, T.A.; Vannella, K.M. Macrophages in Tissue Repair, Regeneration, and Fibrosis. Immunity 2016, 44, 450-462. [CrossRef] [PubMed]

5. Davies, L.C.; Jenkins, S.J.; Allen, J.E.; Taylor, P.R. Tissue-resident macrophages. Nat. Immunol. 2013, 14, $986-995$.

6. $\quad$ Bang, F.B.; Warwick, A. Macrophages and mouse hepatitis. Virology 1959, 9, 715-717. [CrossRef]

7. Evans, R.; Alexander, P. Mechanism of immunologically specific killing of tumour cells by macrophages. Nature 1972, 236, 168-170. [CrossRef]

8. Polacek, D.; Bech, F.; McKinsey, J.F.; Davies, P.F. Connexin43 gene expression in the rabbit arterial wall: Effects of hypercholesterolemia, balloon injury and their combination. J. Vasc. Res. 1997, 34, 19-30. [CrossRef]

9. Dosch, M.; Zindel, J.; Jebbawi, F.; Melin, N.; Sanchez-Taltavull, D.; Stroka, D.; Candinas, D.; Beldi, G. Connexin-43-dependent ATP release mediates macrophage activation during sepsis. elife 2019, 8, e42670. [CrossRef]

10. Hopper, K.E.; Wood, P.R.; Nelson, D.S. Macrophage heterogeneity. Vox Sang. 1979, 36, 257-274. [CrossRef]

11. Laird, D.W.; Lampe, P.D. Therapeutic strategies targeting connexins. Nat. Rev. Drug Discov. 2018, 17, 905-921. [CrossRef]

12. Dbouk, H.A.; Mroue, R.M.; El-Sabban, M.E.; Talhouk, R.S. Connexins: A myriad of functions extending beyond assembly of gap junction channels. Cell Commun. Signal. 2009, 12, 4. [CrossRef] [PubMed]

13. Ribeiro-Rodrigues, T.M.; Martins-Marques, T.; Morel, S.; Kwak, B.R.; Girão, H. Role of connexin 43 in different forms of intercellular communication-Gap junctions, extracellular vesicles and tunnelling nanotubes. J. Cell. Sci. 2017, 130, 3619-3630. [CrossRef] [PubMed]

14. Stout, C.; Goodenough, D.A.; Paul, D.L. Connexins: Functions without junctions. Curr. Opin. Cell Biol. 2004, 16, 507-512. [CrossRef] [PubMed]

15. Pfenniger, A.; Wohlwend, A.; Kwak, B.R. Mutations in connexin genes and disease. Eur. J. Clin. Investig. 2011, 41, 103-116. [CrossRef] [PubMed]

16. Reaume, A.G.; de Sousa, P.A.; Kulkarni, S.; Langille, B.L.; Zhu, D.; Davies, T.C.; Juneja, S.C.; Kidder, G.M.; Rossant, J. Cardiac malformation in neonatal mice lacking connexin43. Science 1995, 267, 1831-1834. [CrossRef]

17. Tittarelli, A.; Navarrete, M.; Gleisner, M.A.; Gebicke-Haerter, P. Connexin-Mediated Signaling at the Immunological Synapse. Int. J. Mol. Sci. 2020, 21, 3736. [CrossRef]

18. Westphalen, K.; Gusarova, G.A.; Islam, M.N.; Subramanian, M.; Cohen, T.S.; Prince, A.S.; Bhattacharya, J. Sessile alveolar macrophages communicate with alveolar epithelium to modulate immunity. Nature 2014, 506, 503-506. [CrossRef]

19. Beckmann, A.; Grissmer, A.; Meier, C.; Tschernig, T. Intercellular communication between alveolar epithelial cells and macrophages. Ann. Anat. 2020, 227, 151417. [CrossRef]

20. Hulsmans, M.; Clauss, S.; Xiao, L.; Aguirre, A.D.; King, K.R.; Hanley, A.; Nahrendorf, M. Macrophages Facilitate Electrical Conduction in the Heart. Cell 2017, 169, 510-522.e20. [CrossRef]

21. Eugenín, E.A.; Brañes, M.C.; Berman, J.W.; Sáez, J.C. TNF-alpha plus IFN-gamma induce connexin43 expression and formation of gap junctions between human monocytes/macrophages that enhance physiological responses. J. Immunol. 2003, 170, 1320-1328. [CrossRef]

22. Qin, J.; Zhang, G.; Zhang, X.; Tan, B.; Lv, Z.; Liu, M.; Ren, H.; Qian, M.; Du, B. TLR-Activated Gap Junction Channels Protect Mice against Bacterial Infection through Extracellular UDP Release. J. Immunol. 2016, 196, 1790-1798. [CrossRef] [PubMed] 
23. Gutstein, D.E.; Morley, G.E.; Tamaddon, H.; Vaidya, D.; Schneider, M.D.; Chen, J.; Chien, K.R.; Stuhlmann, H.; Fishman, G.I. Conduction slowing and sudden arrhythmic death in mice with cardiac-restricted inactivation of connexin43. Circ. Res. 2001, 88, 333-339. [CrossRef] [PubMed]

24. Chadjichristos, C.E.; Matter, C.M.; Roth, I.; Sutter, E.; Pelli, G.; Lüscher, T.F.; Chanson, M.; Kwak, B.R. Reduced connexin43 expression limits neointima formation after balloon distension injury in hypercholesterolemic mice. Circulation 2006, 113, 2835-2843. [CrossRef] [PubMed]

25. Shen, C.; Chen, J.H.; Lee, Y.; Hassan, M.M.; Kim, S.J.; Choi, E.Y.; Hong, S.T.; Park, B.H.; Park, J.H. mTOR- and SGK-Mediated Connexin 43 Expression Participates in Lipopolysaccharide-Stimulated Macrophage Migration through the iNOS/Src/FAK Axis. J. Immunol. 2018, 201, 2986-2997. [CrossRef] [PubMed]

26. Glass, A.M.; Wolf, B.J.; Schneider, K.M.; Princiotta, M.F.; Taffet, S.M. Connexin43 is dispensable for phagocytosis. J. Immunol. 2014, 190, 4830-4835. [CrossRef]

27. Oviedo-Orta, E.; Errington, R.J.; Evans, W.H. Gap junction intercellular communication during lymphocyte transendothelial migration. Cell Biol. Int. 2002, 26, 253-263. [CrossRef]

28. Morel, S.; Chanson, M.; Nguyen, T.D.; Glass, A.M.; Richani Sarieddine, M.Z.; Meens, M.J.; Burnier, L.; Kwak, B.R.; Taffet, S.M. Titration of the gap junction protein Connexin43 reduces atherogenesis. Thromb. Haemost. 2014, 112, 390-401. [CrossRef]

29. Huang, Y.; Mao, Z.; Zhang, Z.; Obata, F.; Yang, X.; Zhang, X.; Huang, Y.; Mitsui, T.; Fan, J.; Takeda, M.; et al. Connexin43 Contributes to Inflammasome Activation and Lipopolysaccharide-Initiated Acute Renal Injury via Modulation of Intracellular Oxidative Status. Antioxid. Redox Signal. 2019, 31, 1194-1212. [CrossRef]

30. Anand, R.J.; Dai, S.; Gribar, S.C.; Richardson, W.; Kohler, J.W.; Hoffman, R.A.; Hackam, D.J. A role for connexin43 in macrophage phagocytosis and host survival after bacterial peritoneal infection. J. Immunol. 2008, 181, 8534-8543. [CrossRef]

31. Morris, L.; Crocker, P.R.; Gordon, S. Murine fetal liver macrophages bind developing erythroblasts by a divalent cation-dependent hemagglutinin. J. Cell Biol. 1988, 106, 649-656. [CrossRef]

32. Austyn, J.M.; Gordon, S. F4/80, a monoclonal antibody directed specifically against the mouse macrophage. Eur. J. Immunol. 1981, 11, 805-815. [CrossRef] [PubMed]

33. Mazzini, E.; Massimiliano, L.; Penna, G.; Rescigno, M. Oral tolerance can be established via gap junction transfer of fed antigens from CX3CR1 ${ }^{+}$macrophages to $\mathrm{CD} 103^{+}$dendritic cells. Immunity 2014, 40, 248-261. [CrossRef] [PubMed]

34. Joly, E.; Hudrisier, D. What is trogocytosis and what is its purpose? Nat. Immunol. 2003, 4, 815. [CrossRef]

35. Smyth, L.A.; Hervouet, C.; Hayday, T.; Becker, P.D.; Ellis, R.; Lechler, R.I.; Lombardi, G.; Klavinskis, L.S. Acquisition of MHC:peptide complexes by dendritic cells contributes to the generation of antiviral CD8+ T cell immunity in vivo. J. Immunol. 2012, 189, 2274-2282. [CrossRef] [PubMed]

36. Wakim, L.M.; Bevan, M.J. Cross-dressed dendritic cells drive memory CD8+ T-cell activation after viral infection. Nature 2011, 471, 629-632. [CrossRef]

37. Okafo, G.; Prevedel, L.; Eugenin, E. Tunneling nanotubes (TNT) mediate long-range gap junctional communication: Implications for HIV cell to cell spread. Sci. Rep. 2017, 7, 16660. [CrossRef]

38. De Couto, G. Macrophages in cardiac repair: Environmental cues and therapeutic strategies. Exp. Mol. Med. 2019, 51, 1-10. [CrossRef]

39. Rosenthal, N. A Guardian of the Heartbeat. N. Engl. J. Med. 2017, 377, 84-86. [CrossRef]

40. Manning, B.D.; Cantley, L.C. AKT/PKB signaling: Navigating downstream. Cell 2007, 129, 1261-1274. [CrossRef]

41. Al-Ghadban, S.; Kaissi, S.; Homaidan, F.R.; Naim, H.Y.; El-Sabban, M.E. Cross-talk between intestinal epithelial cells and immune cells in inflammatory bowel disease. Sci. Rep. 2016, 6, 29783. [CrossRef]

42. Caillou, B.; Talbot, M.; Weyemi, U.; Pioche-Durieu, C.; Al Ghuzlan, A.; Bidart, J.M.; Chouaib, S.; Schlumberger, M.; Dupuy, C. Tumor-associated macrophages (TAMs) form an interconnected cellular supportive network in anaplastic thyroid carcinoma. PLoS ONE 2011, 6, e22567. [CrossRef] [PubMed]

43. Bermudez-Fajardo, A.; Ylihärsilä, M.; Evans, W.H.; Newby, A.C.; Oviedo-Orta, E. CD4+ T lymphocyte subsets express connexin 43 and establish gap junction channel communication with macrophages in vitro. J. Leukoc. Biol. 2007, 82, 608-612. [CrossRef] [PubMed]

44. Eugenín, E.A.; González, H.E.; Sánchez, H.A.; Brañes, M.C.; Sáez, J.C. Inflammatory conditions induce gap junctional communication between rat Kupffer cells both in vivo and in vitro. Cell. Immunol. 2007, 247, 103-110. [CrossRef] [PubMed]

45. Lu, Y.; Wang, X.M.; Yang, P.; Han, L.; Wang, Y.Z.; Zheng, Z.H.; Wu, F.; Zhang, W.J.; Zhang, L. Effect of gap junctions on RAW264.7 macrophages infected with H37Rv. Medicine (Baltimore) 2018, 97, e12125. [CrossRef]

46. Zumerle, S.; Calì, B.; Munari, F.; Angioni, R.; Di Virgilio, F.; Molon, B.; Viola, A. Intercellular Calcium Signaling Induced by ATP Potentiates Macrophage Phagocytosis. Cell Rep. 2019, 27, 1-10.e4. [CrossRef]

47. Junger, W.G. Immune cell regulation by autocrine purinergic signalling. Nat. Rev. Immunol. 2011, 11, 201-212. [CrossRef]

48. Dosch, M.; Gerber, J.; Jebbawi, F.; Beldi, G. Mechanisms of ATP Release by Inflammatory Cells. Int. J. Mol. Sci. 2018, 19, 1222. [CrossRef]

49. Corriden, R.; Insel, P.A. Basal release of ATP: An autocrine-paracrine mechanism for cell regulation. Sci. Signal. 2010, 3, re1. [CrossRef] 
50. Fortes, F.S.; Pecora, I.L.; Persechini, P.M.; Hurtado, S.; Costa, V.; Coutinho-Silva, R.; Goldenberg, R.C. Modulation of intercellular communication in macrophages: Possible interactions between GAP junctions and P2 receptors. J. Cell Sci. 2004, 117, 4717-4726. [CrossRef]

51. Csóka, B.; Németh, Z.H.; Törő, G.; Idzko, M.; Zech, A.; Koscsó, B.; Spolarics, Z.; Antonioli, L.; Cseri, K.; Erdélyi, K.; et al. Extracellular ATP protects against sepsis through macrophage P2X7 purinergic receptors by enhancing intracellular bacterial killing. FASEB J. 2015, 29, 3626-3637. [CrossRef]

52. Greve, A.S.; Skals, M.; Fagerberg, S.K.; Tonnus, W.; Ellermann-Eriksen, S.; Evans, R.J.; Linkermann, A.; Praetorius, H.A. P2X1, P2X4, and P2X7 Receptor Knock Out Mice Expose Differential Outcome of Sepsis Induced by $\alpha$-Haemolysin Producing Escherichia coli. Front. Cell. Infect. Microbiol. 2017, 7, 113. [CrossRef] [PubMed]

53. Lecut, C.; Faccinetto, C.; Delierneux, C.; van Oerle, R.; Spronk, H.M.; Evans, R.J.; El Benna, J.; Bours, V.; Oury, C. ATP-gated P2X1 ion channels protect against endotoxemia by dampening neutrophil activation. J. Thromb. Haemost. 2012, 10, 453-465. [CrossRef] [PubMed]

54. Maître, B.; Magnenat, S.; Heim, V.; Ravanat, C.; Evans, R.J.; de la Salle, H.; Gachet, C.; Hechler, B. The P2X1 receptor is required for neutrophil extravasation during lipopolysaccharide-induced lethal endotoxemia in mice. J. Immunol. 2015, 194, 739-749. [CrossRef] [PubMed]

55. Gomes, D.A.; Song, Z.; Stevens, W.; Sladek, C.D. Sustained stimulation of vasopressin and oxytocin release by ATP and phenylephrine requires recruitment of desensitization-resistant P2X purinergic receptors. Am. J. Physiol. Regul. Integr. Comp. Physiol. 2009, 297, R940-R949. [CrossRef] [PubMed]

56. Rodríguez-Rodríguez, R.; Yarova, P.; Winter, P.; Dora, K.A. Desensitization of endothelial P2Y1 receptors by PKC-dependent mechanisms in pressurized rat small mesenteric arteries. Br. J. Pharmacol. 2009, 158, 1609-1620. [CrossRef] [PubMed]

57. Kang, J.; Kang, N.; Lovatt, D.; Torres, A.; Zhao, Z.; Lin, J.; Nedergaard, M. Connexin 43 hemichannels are permeable to ATP. J. Neurosci. 2008, 28, 4702-4711. [CrossRef]

58. Li, W.; Bao, G.; Chen, W.; Qiang, X.; Zhu, S.; Wang, S.; He, M.; Ma, G.; Ochani, M.; Al-Abed, Y.; et al. Connexin 43 Hemichannel as a Novel Mediator of Sterile and Infectious Inflammatory Diseases. Sci. Rep. 2018, 8, 166. [CrossRef]

59. Mosser, D.M.; Edwards, J.P. Exploring the full spectrum of macrophage activation. Nat. Rev. Immunol. 2008, 8, 958-969. [CrossRef]

60. Martinez, F.O.; Gordon, S. The M1 and M2 paradigm of macrophage activation: Time for reassessment. F1000Prime Rep. 2014, 6, 13. [CrossRef]

61. Sica, A.; Mantovani, A. Macrophage plasticity and polarization: In vivo veritas. J. Clin. Invest. 2012, 122, 787-795. [CrossRef]

62. Cui, K.; Ardell, C.L.; Podolnikova, N.P.; Yakubenko, V.P. Distinct Migratory Properties of M1, M2, and Resident Macrophages Are Regulated by $\alpha \mathrm{D} \beta 2$ and $\alpha \mathrm{M} \beta 2$ Integrin-Mediated Adhesion. Front. Immunol. 2018, 9, 2650. [CrossRef] [PubMed]

63. Novak, M.L.; Koh, T.J. Macrophage phenotypes during tissue repair. J. Leukoc. Biol. 2013, 93, 875-881. [CrossRef] [PubMed]

64. Wu, L.; Chen, K.; Xiao, J.; Xin, J.; Zhang, L.; Li, X.; Li, L.; Si, J.; Wang, L.; Ma, K. Angiotensin II induces RAW264.7 macrophage polarization to the M1-type through the connexin 43/NF-kB pathway. Mol. Med. Rep. 2020, 21, 2103-2112. [CrossRef] [PubMed]

65. Dandona, P.; Dhindsa, S.; Ghanim, H.; Chaudhuri, A. Angiotensin II and inflammation: The effect of angiotensin-converting enzyme inhibition and angiotensin II receptor blockade. Ann. NY Acad. Sci. 2007, 21, 20-27. [CrossRef] [PubMed]

66. Orecchioni, M.; Ghosheh, Y.; Pramod, A.B.; Ley, K. Macrophage Polarization: Different Gene Signatures in M1(LPS+) vs. Classically and M2(LPS-) vs. Alternatively Activated Macrophages. Front. Immunol. 2020, 25, 234. [CrossRef]

67. Yu, X.H.; Fu, Y.C.; Zhang, D.W.; Yin, K.; Tang, C.K. Foam cells in atherosclerosis. Clin. Chim. Acta 2013, 424, 245-252. [CrossRef]

68. Herde, K.; Hartmann, S.; Brehm, R.; Kilian, O.; Heiss, C.; Hild, A.; Alt, V.; Bergmann, M.; Schnettler, R.; Wenisch, S. Connexin 43 expression of foreign body giant cells after implantation of nanoparticulate hydroxyapatite. Biomaterials 2007, 28, $4912-4921$. [CrossRef]

69. Wenisch, S.; Cavalcanti-Adam, E.A.; Tryankowski, E.; Raabe, O.; Kilian, O.; Heiss, C.; Alt, V.; Arnhold, S.; Schnettler, R. Light- and transmission-electron-microscopic investigations on distribution of CD44, connexin 43 and actin cytoskeleton during the foreign body reaction to a nanoparticular hydroxyapatite in mini-pigs. Acta Biomater. 2012, 8, 2807-2814. [CrossRef] 